\title{
Business games and creativity: a bibliometric study and research themes
}

\author{
Marcela Silva Cavalcanti Rosa (D), Mariana Rodrigues de Almeida, Mario Orestes Aguirre González \\ Departamento de Engenharia de Produçacoo, Universidade Federal do Rio Grande do Norte - UFRN \\ e-mails: marcela.cavalcantir@gmail.com; almeidamariana@yahoo.com; mari@ct.ufrn.br
}

\begin{abstract}
This paper presents a bibliometric study of the relationship between business games and creativity and points out gaps in the proposal of research topics. For this, we performed a detailed analysis of 64 articles obtained through a systematic review of the literature, gathered from the Scopus and Web of Science platforms in the areas of business and engineering, published between 1970 and 2016. The data was analyzed by descriptive statistical analysis with the support of the affinity matrix. The results identify: 1) the main research method in this theme is the case study with a qualitative approach; 2) the United States, Canada and China are the countries that publish the most; 3 ) there has been an increase in publications on this topic in recent years; 4) the main sector for application of studies on this theme is the educational one, followed by the business sector; and 5) considering both creativity and business games, exploratory studies are predominant. For future research it is recommended: 1) to analyze the influence of creativity principles in business games; 2) research what are the constituent elements of a business game; 3 ) investigate how a game can stimulate or mediate the creative process of its participants.
\end{abstract}

Keywords: bibliometric study, business game, collective creativity, systematic literature review.

\section{Introduction}

Creativity has been a growing topic of interest in many studies since the early 1950s, when Joy Paul Guilford, president of the American Psychological Association, made a speech encouraging its research (ROWETON, 1989; CHUANG; LIU; SHIU, 2014). The theme is studied by different areas of knowledge such as: psychology (AMABILE, 1988), administration (AGOGUÉ; LEVILLAIN; HOOGE, 2015), marketing (KOTLER, 2009) and engineering (HESMER et al., 2011) and each interpretation considers key aspects of its area of application, without a standard concept to define the term. Interpretations regarding creativity perceive it as something intrinsic to human beings or as a skill that can be stimulated.

On the other hand, it has been observed a new research strand relating creativity with technological tools such as business games (ROSA et al., 2017). There is a convergence between the researches of these themes, with the objective of investigating the cognitive and behavioral effect of the games on the players and their influence on the individual and collective performance among organizations. This is because the use of games for the purpose of generating ideas is an efficient and productive way to carry out the process (HESMER et al., 2011).

Research (SCHWEIGER; ANDERSON; LOCKE, 1985; KNOTTS JUNIOR; KEYS, 1997; HEMZO; LEPSCH, 2006; JONES, 2007, LAU, 2012; IHAMÄKI, 2014; GUDIKSEN, 2015; LAMB, 2016) shows that games are now widely used as a learning aid, especially in schools. However, the use of a business game for this purpose dates back only to the 1950's (LOPES, 2001). This is due to the fact there is a difficulty in identifying them as a serious method of action.

Minina and Nikitina (2012) argue that games are attractive because the creation and sharing of knowledge happens at the same time as the emotional exchanges - which are natural for human beings; learning and playing are basic processes of human existence and reflect the development of skills needed to solve problems, act independently, and other factors.

Several studies have addressed the theme of business games in recent years. Some researches relate business games to the individual's learning factor (LAU, 2012; IHAMAKI, 2014; LAMB, 2016), or as a teaching tool in management and marketing schools (SCHWEIGER; ANDERSON; LOCKE, 1985; HEMZO; LEPSCH, 2006; ADRIAN, 2014).

Other authors focus on the technological aspect of game development (AHAMER; SCHREI, 2006; MININA; NIKITINA, 2012; KERGA et al., 2014) or specific studies for an industry (SAVOLAINEN, 1997; ZACKARIASSON et al., 2006; ROQUILLY, 2011), but few correlate a game with the creative aspect (AGOGUÉ; LEVILLAIN; HOOGE, 2015). Due to the vastness of interests and approaches, mapping the area becomes even more important. 
Thus, this article investigates the current panorama of business games and its relation with creativity, in order to 1) map the current state of art on the theme; and 2) identify the profile of these publications in relation to their classificatory character. With this, we intend to contribute to this universe of research evidencing not only the appropriate practices for the investigation of the theme and but also the existent gaps in the literature.

The article is configured in the following structure: In this first section there is an introduction to the theme. In the second and third sections there are a revision of the theoretical reference on the themes of creativity and business games, selected through the filters established in the method of study used and detailed in the fourth section. Then, the results collected through the interpretation of the data are presented together with the discussion of the topic in the fifth session and, finally, we consider the advances proposed by this study for the subject in question.

However, analyzing a broad and dissimilar research area with fuzzy boundaries between topics could be very complex (MINGERS; LEYDESDORFF, 2015). In this sense, a bibliometric study evidences the current research panorama on the subject mapping the pertinent aspects and facilitating the visualization of gaps and practices adopted in this field. As Završnik et al. (2016, p. 1279) state, "[...] bibliometric mapping represents the use of quantitative methods for visual representation of scientific publications based on bibliographic data".

With this approach, first we use a descriptive bibliometric analysis to identify the world scenario including the most productive countries, increase of publications through the years, main research methods and approaches, main authors involved with this theme, keywords relevance and area of interest of the studies. Then, we applied a technique for visualizing the connection of authors and the network path of research aided by Polinode.

This analysis will provide researchers with useful information regarding publication trends, gathering information from 1970 to 2016, therefore presenting up-to-date data about this issue.

\section{Theorical background}

\subsection{Creativity}

Based on the literature review it is reasonable to point out that is no consensus among the authors about the concept of creativity and its meaning can vary from something natural to the human being to something that can be stimulated and developed. This is not a linear concept and today it is still perceived in both ways, depending on the author in question.

Such streams of thought are well represented by Schumpeter's (2002, p. 413) definition: $[\ldots]$ in which a minority of people with keen intelligence and agile imagination perceive infinite new combinations, look at everyday events with more eyes open-mindedness and a wealth of ideas emerge as suggestions on their own

and Amabile's (1988, p. 132) where:

[...] relevant skills for creativity depend on training, through which they can be explicitly taught, or simply from experience in generate ideas, through which an individual can develop their strategies of creative thinking.

Therefore we call them intrinsic creativity and stimulated creativity. The concept of inherent creativity is understood to be a product of the intelligence or geniality of people, born with a different sensibility and worldview, and this creativity comes from the behavior of the individual - it is intrinsic to his/her and his/her personality. The second stream understands that creativity means something that can be learned and provoked through exchanges with the environment and appropriate stimuli, being possible to develop creative potential.

However, we identified that other authors perceive creativity as a fundamental part of the innovation process. Rothwell (1992) presented a model in the 1970's that links the technology-driven innovation pattern with the one pulled by the market for the consumer's needs. This model presents the innovation process in five steps: 1) Generating ideas; 2) Development; 3) Prototyping; 4) Manufacturing; and, 5) Marketing and sales. Creativity then becomes to be understood no longer as an abstract feature, but as part of an ideation and development process (HESMER et al., 2011; MARINHO et al., 2016).

It is plausible to interpret the ideation process in a group from two different perspectives: the ability to socialize peripheral ideas (HARGADON; SUTTON, 1997) and the ability to create a creative climate (AMABILE, 1983). Both factors have an impact on the collective capacity of ideation, enabling the fostering of interaction between all parties involved in the process.

Nonaka and Takeuchi (1995) warn that the creation of knowledge feeds innovation, but knowledge itself does not. To do so, teams have a central role in creating content by promoting interaction and constant dialogue, and from that, create new points of view that integrate different individual angles of perception regarding the same issue from a collective perspective.

Creative learning is identified as a process of collaboration and purpose (MCWILLIAM; DAWSON, 2008), and in this process groups allow the creation of a synergism in which the whole is much more than the sum of the parts (JONES, 2002; LEOPOLDINO; GONZÁLEZ; MARQUES JUNIOR, 2016). However, it is possible to observe that the process of generating ideas faces broad challenges to effectively manage the induction of knowledge 
and creativity in a collective activity (NONAKA, 1991; NONAKA; TAKEUCHI, 1995).

According to Miller $(1987,1999)$ there are two ways to approach creativity in a group: using linear approaches or using intuitive approaches. The first focuses on helping the group to understand their problem clearly and to generate creative ideas through one or more pre-established techniques. The second expects the group to reach its inner calm state to generate creative solutions, while the whole process happens without fixed structure, being able to make use of varied techniques.

Therefore it is plausible to note the direct relationship between the ideation process and creativity, as well as its contextualization in the scope of innovation. In addition we can observe how creative learning is a process of interaction that can be approached from different perspectives.

\subsection{Business games}

Games are not a new form of interaction (DETERDING et al., 2011) but have been used in different areas of knowledge for different purposes, such as: health care, empowering caregivers of patients with dementia in creative techniques (SISARICA et al., 2013); in engineering, with the design of lean production in the development of a product (KERGA et al., 2013); and in economy, to simulate market behavior and the impact of new regulations (KNEZ; CAMERER, 1994).

As investigated by Keys and Wolfe (1990, p. 307):

[...] business games emerged in the late 1950's, generated by a development landscape in war games, operations research, computational technology, and education theory

but only by the mid-1970's players began to be able to make strategic decisions in addition to conventional budget decisions (WOLFE, 1978). Until the 1980's, thousands of teachers from different educational institutions made use of business games, an index that continued to grow over the next decade (FARIA, 1998).

Susi, Johannesson and Backlund (2007) address the discussion regarding the conceptualization of business games not being completely accepted and therefore divergent among various authors. The authors question the conception of this type of game and point out the need for a new definition that includes the main core of business games approach.

For Agogué, Levillain and Hooge (2015, p. 416) a serious game is perceived as a:

[...] reality simulation with roleplaying, which provides an immersive experience in which participants must make decisions, act and react to events and develop strategies to achieve one or more goals.

The use of these games goes beyond the business environment and even the educational environment, although very useful for training and teaching purposes. For Schön (1983) the game contains a cognitive process of reflection-by-action, involving 'learning by doing' and in which incipient ideas interact with the outcome of their attempts at expression.

Bogers and Sproedt (2012) argue that games allow us to simulate the social dynamics in which we deal collaboratively with the novelty, and thus constitute a complex social experience, since during the game the understanding and relationships between the players emerge; this is because players need to accept the perspectives given by the game or create new purposes for what they do and the way they do it and therefore modify their perceptions and what they justify as true. This process defies all existing expectations and involves conflicts and failures before reaching success (BOGERS; SPROEDT, 2012).

Thus, business games - or serious games - are simulations of reality that aim to promote learning for its participants. To do so, they provide an atmosphere of immersion and engagement in which players exercise decision-making skills, reflection, communication improvement, creativity, understanding of complexity and consensus building in the process to achieve the goals of the game, either individually or in a group. In the midst of this process the game is designed to transfer specific knowledge and information to players who may have conflicting interests.

Hence we perceive there are more factors to be considered in a business game than simply the act of playing. It is pertinent to look at its goal, the possible forms of interaction among the players and even the expected result to be generated from the experience, deciding for a specific type of game according to the goals of the moderator, be they educational or not. In addition, the moments before and after the game should also be considered as part of learning, since they are also contained in the experience.

\section{Research method}

The method used for this research was a systematic literature review. Cook, Mulrow and Haynes (1997) consider that the systematic literature review, compared with the traditional review, includes a clear statement of the purpose of the research, a thorough search of publications, critical evaluation of major publications and the possibility of replication of the research method.

For Webster and Watson (2002) the systematic review aims to generate structured knowledge about a research topic and can be used to make reasonable predictions about the researched topic, while Pai et al. (2004) considers that this type of research is a reliable approach because of its comprehensiveness and explicit presentation of the means and results obtained.

The research was systematized in six phases (Figure 1). The first phase aimed to filter a mapping of the business 


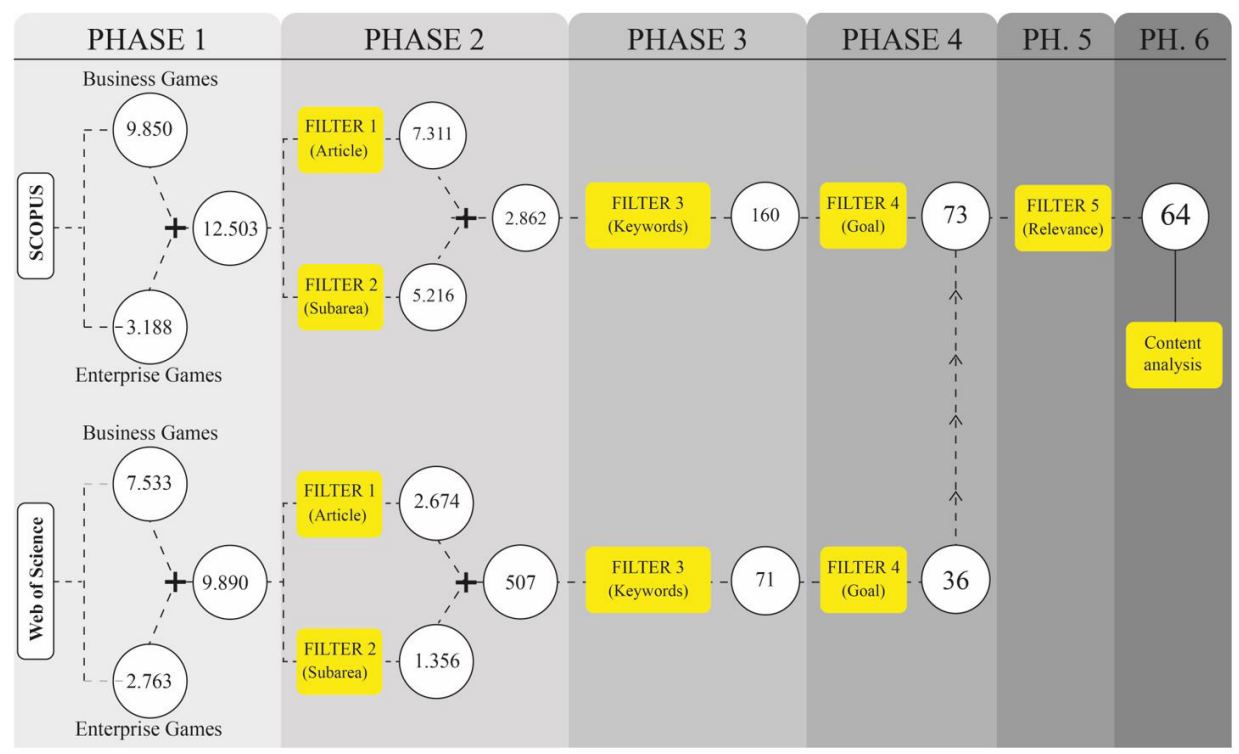

Figure 1. Procedure of systematic literature review.

game state of the art. For this, the initial research on the topic used the terms Business Game and Enterprise Game whose combination showed 12,503 results found in the Scopus platform and 9,890 results in the Web of Science platform, between titles, abstracts and keywords.

Due to the great variety of results it was necessary to establish filters with the purpose of refining the study, represented in phase 2 . The criteria defined to configure the search were: 1) file type - articles; and 2) subareas - engineering and business. Such restrictions reduced results to 2,862 on the Scopus platform and 507 in the Web of Science platform. However the scope of the articles still presented discrepancies in relation to the topic addressed, being necessary the addition of a third filter, for the third phase: 3 ) keywords - creativity, creative, creativity techniques and creative techniques, limiting the scope to 160 articles in Scopus and 71 in the Web of Science.

Next the abstracts of the articles were read and analyzed according to their pertinence for this research, being necessary the adoption of an additional filter for the fourth phase: 4) goal - in which the articles directed to the universes of games, virtual learning, creativity and innovation techniques were selected. The research scope was reduced to 73 articles on the Scopus platform and 36 articles in the Web of Science, which were contained in the set of articles found on the previous platform.

However after reading the articles, some of them were not relevant to the topic which led to the fifth phase and adoption of the last filter: 5) relevance - resulting in a final selection of 64 articles. The data was collected by the end of 2016 and dated back to 1970, with House's paper the simulated city: The use of second generation gaming in studying the urban system.
In the sixth and last phase the articles were read in completeness and their content analyzed, using synthesis tables of the affinity matrix type as a support tool to organize the information collected. The classification criterion was the citation of the topics by the authors. Afterwards the data collected was analyzed and, from this, research topics were proposed to evolve the knowledge regarding the theme.

From the analysis of the references of these 64 articles we gathered 100 other works relevant to the development of the theme, which were used in the construction of this theoretical framework. However, the analysis of the merit of the research focuses on the 64 articles collected through the systematic bibliographic review.

\section{Results and discussion}

We carried out the descriptive analysis of the 64 articles based on the criteria: 1) typology of the articles; 2) keywords relevance; 3 ) countries with most publications on the theme; 4) chronology of publications, demonstrating the interest for this theme over the years; 5) research method; 6) technique of analysis; 7) which journals publish more about the theme; and 8 ) the areas of application of the studies.

The combination of these aspects evidences the total stratification of the sample and the complexity of data that can be abstracted and interpreted from the results of a systematic bibliographic review. To illustrate this process visually we presented the research network diagram (Figure 2), which contextualizes the presence of each research theme and the connection between the areas, exemplified by citations.

As for the typology of the articles regarding the formatting of research in theory and practice (Table 1) we utilized the work of Demo (1994), which defines theoretical 
research as a type of research that elaborates and improves theoretical foundations as concepts and ideologies, while practical research presupposes practical intervention with methodological rigor.

The recurrence of the keywords found in the selected sample (Table 2) allowed us to prove the relevance of the research process and to exemplify that the themes of

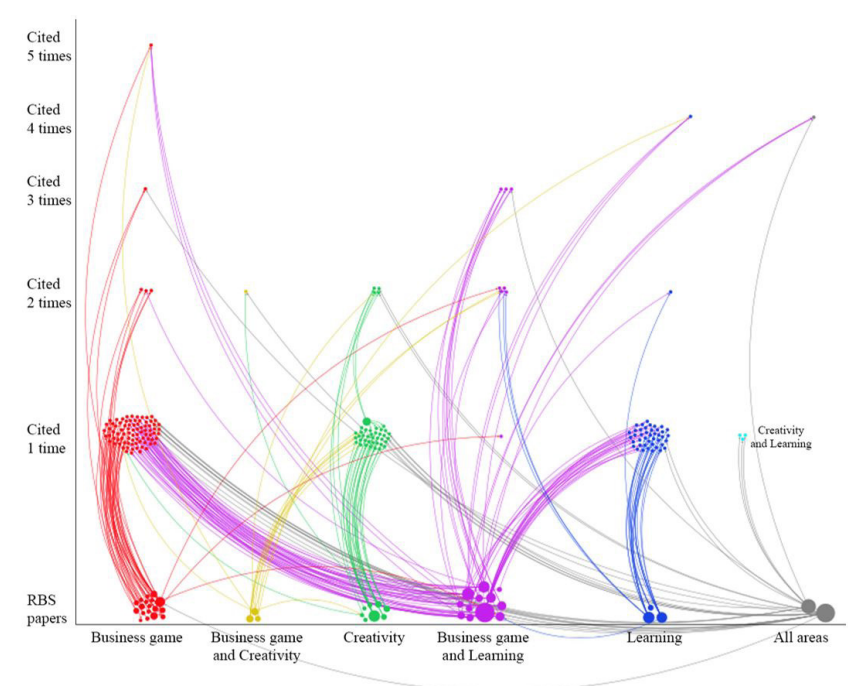

Figure 2. Research network diagram.

Table 2. Keywords relevance.

\begin{tabular}{|l|c|c|c|c|}
\hline \multirow{2}{*}{ Keywords } & \multicolumn{2}{|c|}{ Articles } & \multirow{2}{*}{ Keyword Relevance* } & \multirow{2}{*}{ Total Relevance* } \\
\cline { 2 - 3 } & Total & Relevant & $81.25 \%$ & $20.3 \%$ \\
\hline Learning & 16 & 13 & $34.78 \%$ & $12.5 \%$ \\
\hline Creativity & 23 & 8 & $100 \%$ & $6.2 \%$ \\
\hline Gamification & 4 & 4 & $36.36 \%$ & $12.5 \%$ \\
\hline Innovation & 22 & 8 & $55.38 \%$ & $56.2 \%$ \\
\hline Games & 65 & 36 & $44 \%$ & $17.2 \%$ \\
\hline Not Informed & 25 & 11 & $21.42 \%$ & $14.1 \%$ \\
\hline Other words & 42 & 9 & & \\
\hline
\end{tabular}

*Percentage obtained taking into consideration the number of articles indicated in the total of 64 articles.

Number of Publications per Country

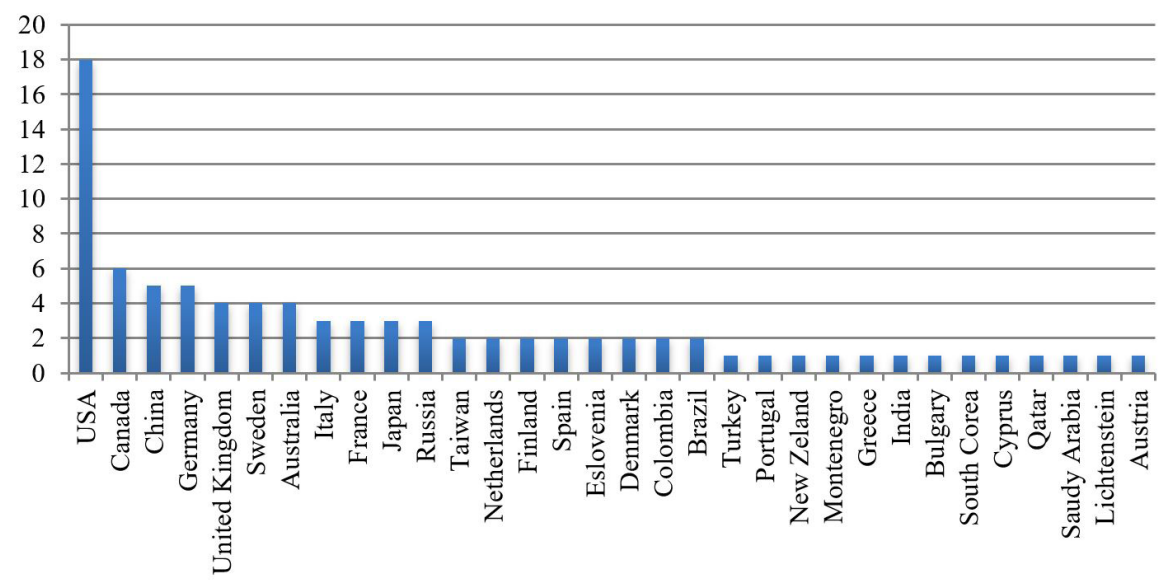

Graph 1. Number of publications per country. 
majority (HOUSE, 1970; SCHWEIGER; ANDERSON; LOCKE, 1985; JALAN; KLEINER, 1995; BOS; SHAMI; NAAB, 2006).

Canada, second place in the list, mainly studies the aspects of learning and business, represented by research of the authors Miller, Olleros and Molinié (2008), Karime et al. (2012), and Agogué, Levillain and Hooge (2015). China and Germany are third on the list. China has a dispersed focus, although technology is the most recurrent theme found in the works Lai and Leung (2015), Jianmei (2010) and Lau (2012). Germany presents a business focus based on technologies and systematizations registered in the research of Markides and Anderson (2006), Storz (2008), and Hesmer et al. (2011).

The United Kingdom also presents a range of varied approaches but focuses mainly on technology and social factors represented in the research of Markides and Anderson (2006), Robson et al. (2015), Lai and Leung (2015), Wodehouse and Bradley (2006) and Wright (2015).

Another pertinent issue is the relationship between the year and the number of publications on the topic, which allows us to outline a chronology and to understand the relevance of the subject over time (Graph 2), and in a second instance, the pertinence of these articles and its repercussion for the academic community - identified through the number of citations of each article.

We can verify that the number of publications is relatively low, but the repercussion of the articles has reached high indexes of citations. This demonstrates the expanded scope of some articles for the literature on the subject in the year of 1998 and later, between the years 2006 and 2010. In a superficial analysis one can observe a renewed interest in the subject in recent years.

Still on this topic we identified a pattern of approach regarding the most used research methods in this area. This paper identified the case study as the most used method, with approximately $70 \%$ of the articles using this choice (Table 3), applied with a qualitative approach, represented with $50 \%$ index of the analyzed studies (Table 4 ). In addition, the most recurrent typology in the articles is theoretical, as demonstrated previously (Table 1).

With these factors identified we delineated an archetype of the journals connected to the theme, identified from the individual index of publications. This allowed us to draw a profile of the degree of involvement of each journal with the matter and the reference items of the area (Table 5).

Ultimately, we performed a stratification of the articles and their content, identifying the focus of interest of each study. We noticed that $51.6 \%$ of the sample showed an inclination of interest for the educational property, so this category was detailed in different aspects: cognitive education, behavioral education, business education and technological education. Besides these, studies showed interest in companies, government, industry, and purely theoretical focus (Table 6).

We observed that some articles refer to more than one area, suggesting the correlation among the themes and the diffuse division of frontiers among the presented approaches. The same study can investigate a game under its cognitive and behavioral aspect and its purpose for

Table 3. Research method.

\begin{tabular}{|l|c|c|}
\hline \multicolumn{1}{|c|}{ Method } & Quantity & Percentage* \\
\hline Case Study & 43 & $67.18 \%$ \\
\hline Literature Review & 11 & $17.18 \%$ \\
\hline Experimental Research & 2 & $3.12 \%$ \\
\hline Survey & 6 & $9.37 \%$ \\
\hline Action Research & 2 & $3.12 \%$ \\
\hline
\end{tabular}

*Percentage obtained taking into consideration the number of articles indicated in the total of 64 articles.

Table 4. Research approach.

\begin{tabular}{|l|c|c|}
\hline \multicolumn{1}{|c|}{ Approach } & Quantity & Percentage* \\
\hline Qualitative & 32 & $50 \%$ \\
\hline Qualitative-quantitative & 28 & $44 \%$ \\
\hline Quantitative & 4 & $6 \%$ \\
\hline
\end{tabular}

*Percentage obtained taking into consideration the number of articles indicated in the total of 64 articles.

\section{Publications Profile}

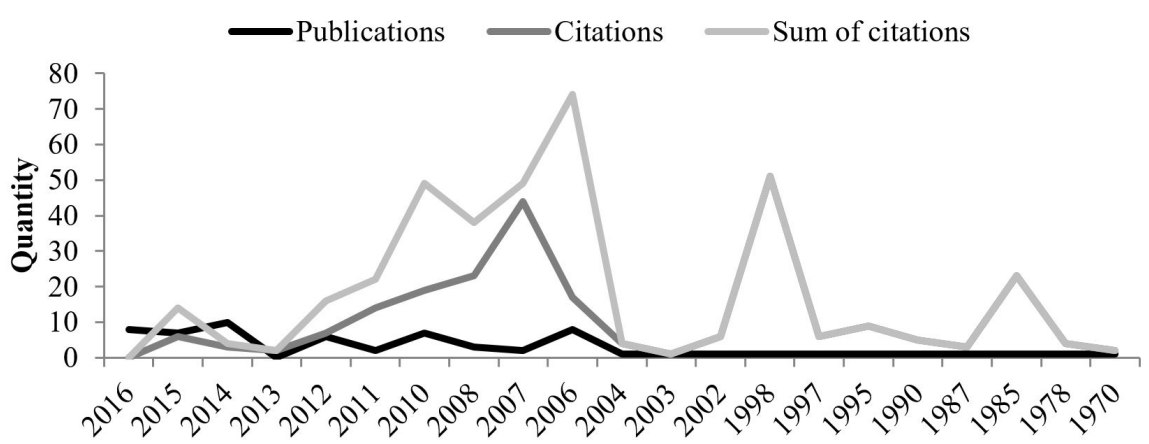

Graph 2. Publications profile. 
business education (BOGERS; SPROEDT, 2012), showing a correlation between the results found.

The importance of education in the research of this topic is well known, and its prominent role - with an index of more than $50 \%$ of the area's research focus - provides space for different approaches, such as those detailed in the table. Companies represent the second group of interest and the governmental content has no relevance. Table 6 shows that games are widely used as a simulation tool for reality, but they usually serve as a teaching and learning tool prior to the actual practice of professional action, or as a test mechanism for new academic and technological perceptions.

Regarding the universe of games we identified, as shown in Table 7, that $65.6 \%$ of the articles focus on computer

Table 5. Number of publications per journal.

\begin{tabular}{|l|c|c|}
\hline \multicolumn{1}{|c|}{ Journal } & Publications & Year \\
\hline Multimedia Tools and Applications & 5 & $2011,2012,2014,2014,2016$ \\
\hline Simulation and Gaming & 5 & $1987,2002,2004,2006,2016$ \\
\hline Journal of Design Research & 4 & $2006,2006,2006,2012$ \\
\hline Journal of Science Education and Technology & 3 & $2014,2016,2016$ \\
\hline Business Horizons & 2 & 2006,2015 \\
\hline Creativity and Innovation management & 2 & 2015,2015 \\
\hline Research Policy & 2 & 2007,2008 \\
\hline Review of Business Management & 2 & 2006,2014 \\
\hline Services Marketing Quarterly & 2 & 2006,2010 \\
\hline
\end{tabular}

Table 6. Articles areas of application.

\begin{tabular}{|c|c|c|c|}
\hline Area & $\begin{array}{l}\text { Number of } \\
\text { Papers }\end{array}$ & Percentage* & Article \\
\hline $\begin{array}{l}\text { Cognitive } \\
\text { Education }\end{array}$ & 20 & $31 \%$ & $\begin{array}{l}\text { House (1970) Wolfe (1978); Keys and Wolfe (1990); Nakamura, Ohsawa and Nishio } \\
\text { (2010); Kostomaj and Boh (2010); Bogers and Sproedt (2012); Lau (2012); Karime et al. } \\
\text { (2012); Chuang, Liu and Shiu (2014); Corredor, Gaydos and Squire (2014); Evain and } \\
\text { De Marco (2014); Ihamäki (2014); Adrian (2014); Agogué, Levillain and Hooge (2015); } \\
\text { Robson et al. (2015); Beuk (2015); Bressler and Bodzin (2016); Geithner and Menzel } \\
\text { (2016); Kutbiddinova, Eromasova and Romanova (2016); Lamb (2016). }\end{array}$ \\
\hline $\begin{array}{l}\text { Behavioral } \\
\text { Education }\end{array}$ & 13 & $20 \%$ & $\begin{array}{l}\text { Schweiger, Anderson and Locke (1985); Keys and Wolfe (1990); Schwartz and Teach } \\
\text { (2002); Hemzo and Lepsch (2006); Johns and Shaw (2006); Bogers and Sproedt (2012); } \\
\text { Lau (2012); Rivera, Domenico and Sauaia (2014); Wright (2015); Ozkan-Canbolat and } \\
\text { Beraha (2016); Bressler, Bodzin (2016); Geithner and Menzel (2016). }\end{array}$ \\
\hline $\begin{array}{l}\text { Business } \\
\text { Education }\end{array}$ & 21 & $33 \%$ & $\begin{array}{l}\text { House (1970); Wolfe (1978); Schweiger, Anderson and Locke (1985); Keys and Wolfe } \\
\text { (1990); Savolainen (1997); Schwartz and Teach (2002); Bots and Hofstede; (2004); Bos, } \\
\text { Shami and Naab (2006); Hemzo and Lepsch(2006); Jones (2007); Miller, Olleros and } \\
\text { Molinié (2008); Bogers and Sproedt (2012); Minina and Nikitina (2012); Mihai-Yiannaki } \\
\text { and Savvides (2012); Ceschi, Dorofeeva and Sartori (2014); Ceschi et al. (2014); Gudiksen } \\
\text { (2015); Beuk (2015); Geithner and Menzel (2016); Ozkan-Canbolat and Beraha (2016); } \\
\text { Soeiro, Santos and Alves (2016). }\end{array}$ \\
\hline $\begin{array}{l}\text { Technological } \\
\text { Education }\end{array}$ & 10 & $16 \%$ & $\begin{array}{l}\text { Ahamer and Schrei (2006); Nakamura, Ohsawa and Nishio (2010); Minina and Nikitina } \\
\text { (2012); Evain and De Marco (2014); Saldana et al. (2014); Kerga et al. (2014); Ihamäki } \\
\text { (2014); Lai and Leung (2015); Kim, Chung and Kang (2015); Marco, Cerezo and } \\
\text { Baldassarri (2016). }\end{array}$ \\
\hline Companies & 29 & $45 \%$ & $\begin{array}{l}\text { House (1970); Jalan and Kleiner (1995); Schwartz and Teach (2002); Rossiter (2003); } \\
\text { Bots and Hofstede (2004); Hemzo and Lepsch (2006); Markides and Anderson (2006); } \\
\text { Walfisz, Zackariasson and Wilson; (2006); Wodehouse and Bradley (2006); Zackariasson, } \\
\text { Walfisz and Wilson; (2006); Harris (2008); Miller, Olleros and Molinié (2008); Storz } \\
\text { (2008); Jianmei (2010); Lee (2010); Seidel, Müller-Wienbergen and Rosemann (2010); } \\
\text { Zackariasson; Wåhlin and Wilson (2010); Hesmer et al. (2011); Roquilly (2011); Fumarola, } \\
\text { Van Staalduinen and Verbraeck (2012); Karime et al. (2012); Nishino (2013); Ceschi, } \\
\text { Dorofeeva and Sartori (2014); Ceschi et al. (2014); Sigala (2015); Wright (2015); Burns } \\
\text { (2016); Vinichenko et al. (2016) }\end{array}$ \\
\hline $\begin{array}{l}\text { Theoretical } \\
\text { Focus }\end{array}$ & 7 & $11 \%$ & $\begin{array}{l}\text { Fritzsche(1987); Keys and Wolfe (1990); Jalan and Kleiner(1995); Haeckel (1998); } \\
\text { Zackariasson and Wilson (2010); Dicheva et al. (2015); Keslacy (2015); }\end{array}$ \\
\hline Government & 1 & $1 \%$ & House (1970). \\
\hline
\end{tabular}

*Percentage obtained taking into consideration the number of articles indicated of a total of 64 articles. 
games and only $23.4 \%$ on manual games. In addition we found that the major focus of research (Table 8) that proposed or analyzed specific games is focused on higher education (40\%), followed by interest in games for basic education (20\%), companies (14\%), leisure (12\%), professionals $(12 \%)$ and government $(2 \%)$.

We understand business games have a didactic purpose since they transmit specific knowledge in a practical and experimental way, developing in the participants the ability to make decisions in the midst of a simulated environment, similar as much as possible to the environment in which they will have to be actually fulfilled (TANABE, 1977).

With the mapping complete we made the intersection of references among the articles and we observed that the authors do not connect, although the subjects investigated are inserted in the same great area of study, listed under the same subareas and use similar keywords. This characteristic drove us to format a network of citations, developed through the identification of relevant reference sources for the collected articles (Figure 2). In Figure 2 is possible to observe the clustering of authors according to the topic addressed and the network of authors obtained from the references of the articles present in the initial bibliography.

Finally, the variety of research referenced have concluded the high relevance of business games in education, being characterized by teachers of administration as one of the didactic resources to be accentuated in the training of the administrator (LOPES, 2001).

In addition to the academic impact, the advance of research in this theme contributes to a social and, consequently, economic impact, since it will help in the formation of new professionals, more aware of the reality that awaits them outside the teaching environment. According to Minina and Nikitina (2012) there is a disproportion in the market between the high demand of professionals, the high number of graduates with low level of competence and the limited number of graduates with a high level of competence.

Table 7. Game platform

\begin{tabular}{|c|c|c|}
\hline Platform & Quantity & Percentage* \\
\hline Computer & 42 articles & $65.6 \%$ \\
\hline Manual & 15 articles & $23.4 \%$ \\
\hline
\end{tabular}

*Percentage obtained taking into consideration the number of articles indicated in the total of 64 articles.

Table 8. Game interest.

\begin{tabular}{|c|c|c|}
\hline Interest of practical games & Quantity & Percentage* \\
\hline Higher Education & 20 & $40 \%$ \\
\hline Basic Education & 10 & $20 \%$ \\
\hline Companies & 7 & $14 \%$ \\
\hline Leisure & 6 & $12 \%$ \\
\hline Professionals & 6 & $12 \%$ \\
\hline Government & 1 & $2 \%$ \\
\hline
\end{tabular}

*Percentage obtained taking into consideration the number of articles indicated in the total of 64 articles.

\section{Conclusion}

This article proposes to map the current state of the art on the theme of business games related to creativity and to identify the profile of these publications, aiming to contribute to this universe of research evidencing the appropriate practices for the investigation of the topic and the existing gaps in the literature.

So, this article contributes to the development of the literature through a detailed bibliometric study analyzed from a systematic review of the literature represented by 64 articles on the subject. In addition we connected authors from different spheres under the same prism, spanning applications in the educational, business, technological and governmental areas as well as detailing the main authors addressing the issue.

The main contribution is the identification of the most used research method (case study) to investigate the theme, as well as the (qualitative) approach, typology of articles (theoretical-practical), main journals, key countries researching the theme, keywords that direct the universe of research, profile of publications in relation to trend (year) and dissemination of knowledge (citations), the most used (digital) game platform and the research focus of these games (educational). To collaborate with the understanding of this research process we elaborated a research network diagram for the graphical representation of the connections among the 64 collected articles and their relevant research universes.

The current research landscape has largely addressed the themes of creativity and more recently business games, although separately. In what concerns the direct correlation between business games and the creative process, investigated in different areas of knowledge and evidenced through the research here presented, we evidenced its positive performance in people's learning capacity, stimulating social and cognitive characteristics, which can provide great potential for results.

Thus we perceive the increasing insertion of business games as a tool to foster a previously established goal, commonly related to cognitive and behavioral aspects. As evidenced in the theoretical framework companies and institutions can use this tool to stimulate creativity, innovation and collaboration among their human resources.

However it is necessary to investigate the subject in depth to show a pattern of response that allows a generalization, linked to determinant and more comprehensive statistical analyzes. In this sense it is necessary to detail the analysis of the results of previous studies on the subject. This research concludes there is a lack of articles relating the two themes and that this gap can and should be further explored. The current approach is only that the game can be used as one of several techniques of the process of ideation (12.5\%) without deepening its merit. 
After analyzing the articles the following questions were identified: 1) what is the influence of the elements of creativity in business games; 2) what are the elements that constitute a business game; 3 ) how a business game can stimulate creativity or mediate the creative process of its participants. Thus for future studies we propose to investigate the effect a business game has on the creativity of its participants, through experimental and action-research with tests in academic and business environments, comprising groups of different genres and ages.

\section{Acknowledgements}

This work was supported by CAPES - Coordenação de Aperfeiçoamento de Pessoal de Nível Superior.

\section{References}

ADRIAN, A. Borrowing experience: ASX share market game. International Journal of Innovation and Learning, v. 16, n. 1, p. 81,2014 . http://dx.doi.org/10.1504/ IJIL.2014.063375.

AGOGUÉ, M.; LEVILLAIN, K.; HOOGE, S. Gamification of creativity: exploring the usefulness of serious games for ideation. Creativity and Innovation Management, v. 24, n. 3, p. 415-429, 2015. http://dx.doi.org/10.1111/caim.12138.

AHAMER, G.; SCHREI, C. Exercise 'technology assessment' through a gaming procedure. Journal of Desert Research, v. 5 , n. 2 , p. $224-252,2006$. http://dx.doi.org/10.1504/ JDR.2006.011364.

AMABILE, T. The social psychology of creativity: a componential conceptualization. Journal of Personality and Social Psychology, v. 45, n. 2, p. 357-376, 1983. http:// dx.doi.org/10.1037/0022-3514.45.2.357.

AMABILE, T. A model of creativity and innovation in organizations. Research in Organizational Behavior, $v$. 10, p. 123-167, 1988.

BEUK, F. Sales simulation games: student and instructor perceptions. Journal of Marketing Education, v. 38, n. 3, p. 1-13, 2015.

BOGERS, M.; SPROEDT, H. Playful collaboration (or not): using a game to grasp the social dynamics of open innovation in innovation and business education. Journal of Teaching in International Business, v. 23, n. 2, p. 75-97, 2012. http://dx.doi.org/10.1080/08975930.2012.718702.

BOS, N.; SHAMI, N.; NAAB, S. A globalization simulation to teach corporate social responsibility: design features and analysis of student reasoning. Simulation \& Gaming, v. 37, n. 1, p. 56-72, 2006. http://dx.doi. org/10.1177/1046878106286187.
BOtS, P.; HOFSTEDE, G. The TAKEOVER TRIO. Simulation \& Gaming, v. 35, n. 4, p. 505-516, 2004. http:// dx.doi.org/10.1177/1046878104263670.

BRESSLER, D.; BODZIN, A. Investigating flow experience and scientific practices during a mobile serious educational game. Journal of Science Education and Technology, v. 25 , n. 5, p. 795-805, 2016. http://dx.doi.org/10.1007/ s10956-016-9639-z.

BURNS, W. The innovation game: how to better find it, embrace it and transform it into explosive growth. Hitachi Review, v. 64, n. 10, p. 681, 2016.

CESCHI, A.; DOROFEEVA, K.; SARTORI, R. Studying teamwork and team climate by using a business. European Journal of Training and Development, v. 38, n. 3, p. 211230, 2014. http://dx.doi.org/10.1108/EJTD-01-2013-0004.

CHUANG, T.; LIU, E.; SHIU, W. Game-based creativity assessment system: the application of fuzzy theory. Multimedia Tools and Applications, v. 74, p. 9141-9155, 2014.

COOK, D.; MULROW, C.; HAYNES, R. Systematic reviews: synthesis of best evidence for clinical decisions. Annals of Internal Medicine, v. 126, n. 5, p. 376-380, 1997. http:// dx.doi.org/10.7326/0003-4819-126-5-199703010-00006.

CORREDOR, J.; GAYDOS, M.; SQUIRE, K. Seeing change in time: video games to teach about temporal change in scientific phenomena. Journal of Science Education and Technology, v. 23, n. 3, p. 324-343, 2014. http://dx.doi. org/10.1007/s10956-013-9466-4.

DEMO, P. Pesquisa e construção do conhecimento: metodologia científica no caminho de Habermas. Rio de Janeiro: Tempo Brasileiro, 1994.

DETERDING, S. et al. From game design elements to gamefulness: defining gamification. In: INTERNATIONAL ACADEMIC MINDTREK CONFERENCE: ENVISIONING FUTURE MEDIA ENVIRONMENTS, 15., 2011, Tampere, Finland. Proceedings... New York: ACM, 2011. p. 9-15. http://dx.doi.org/10.1145/2181037.2181040.

DICHEVA, D. et al. Gamification in education: a systematic mapping study. Journal of Educational Technology \& Society, v. 18, n. 3, p. 75-88, 2015.

EVAIN, C.; DE MARCO, C. Reading with a difference: eZoomBook and MyGame-4. Publishing Research Quarterly, v. 30, p. 50-62, 2014.

FARIA, A. J. Business simulation games: current usage levels. An update. Simulation \& Gaming, v. 29, n. 3, p. 295-308, 1998. http://dx.doi.org/10.1177/1046878198293002.

FRITZSCHE, D. The impact of microcomputers on business educational simulations. Simulation \& 
Games, v. 18, n. 2, p. 176-191, 1987. http://dx.doi. org/10.1177/104687818701800202.

FUMAROLA, M.; VAN STAALDUINEN, J.-P.; VERBRAECK, A. A ten-step design method for simulation games in logistics management. Journal of Computing and Information Science in Engineering, v. 12, p. 011006-1011006-6, 2012.

GEITHNER, S.; MENZEL, D. Effectiveness of learning through experience and reflection in a project management simulation. Simulation \& Gaming, v. 47, n. 2, p. 228-256, 2016. http://dx.doi.org/10.1177/1046878115624312.

GUDIKSEN, S. Business model design games: rules and procedures to challenge assumptions and elicit surprises. Creativity and Innovation Management, v. 24, n. 2, p. 307-322, 2015. http://dx.doi.org/10.1111/caim.12114.

HAECKEL, S. About the nature and future of interactive marketing. Journal of Interactive Marketing, v. 12, n. 1, p. 63-71, 1998. http://dx.doi.org/10.1002/(SICI)15206653(199824)12:1<63::AID-DIR8>3.0.CO;2-C.

HARGADON, A.; SUTTON, R. I. Technology brokering and innovation in a product development firm. Administrative Science Quarterly, v. 42, n. 4, p. 716-749, 1997. http:// dx.doi.org/10.2307/2393655.

HARRIS, P. See how they learn. [S.l.: s.n.], 2008.

HEMZO, M.; LEPSCH, S. Jogos de empresas com foco em marketing estratégico: uma análise factorial da percepção dos participantes. Revista Brasileira de Gestão de Negócios, v. 8, n. 20, p. 2-33, 2006.

HESMER, A. et al. Supporting the ideation processes by a collaborative online based toolset. International Journal of Technology Management, v. 55, n. 3-4, p. 218-225, 2011.

HOUSE, P. The simulated city: the use of second generation gaming in studying the urban system. Socio-Economic Planning Sciences, v. 4, n. 1, p. 97-106, 1970. http://dx.doi. org/10.1016/0038-0121(70)90031-5.

IHAMÄKI, P. GameFlow experience model: undersanding player enjoyment in pervasive adventure geocaching game. International Journal of Wireless and Mobile Computing, v. 7, n. 6, p. 536-548, 2014.

JALAN, A.; KLEINER, B. H. New developments in developing creativity. Journal of Managerial Psychology, v. 10, n. 8, p. 20-23, 1995. http://dx.doi. org/10.1108/02683949510100750.

JIANMEI, Y. An approach applying SSM to problem situations of interests conflicts: Interests-coordination SSM. Systems Research and Behavioral Science, v. 27, n. 2, p. 171-189, 2010. http://dx.doi.org/10.1002/sres.1023.
JOHNS, R.; SHAW, J. Real-time immersive design collaboration: conceptualizing, prototyping and experiencing design ideas. Journal of Desert Research, v. 5, n. 2, p. 172-187, 2006. http://dx.doi.org/10.1504/JDR.2006.011361.

JONES, C. Enterprise education: the frustration of a pure contest. Education + Training, v. 49, n. 8-9, p. 596-605, 2007. http://dx.doi.org/10.1108/00400910710834030.

JONES, G. R. Organizational theory. 4th ed. EUA: Prentice Hall, 2002.

KARIME, A. et al. RFID-based interactive multimídia system for the children. Multimedia Tools and Applications, v. 59 , n. 3, p. $749-774,2012$. http://dx.doi.org/10.1007/ s11042-011-0768-3.

KERGA, E. et al. Lean product development: serious game and evaluation of the learning outcomes. In: EMMANOUILIDIS, C.; TAISCH, M.; KIRITSIS, D. (Eds.). Advances in production management systems: competitive manufacturing for innovative products and services. Heidelberg: Springer, 2013. p. 590-597. http:// dx.doi.org/10.1007/978-3-642-40352-1_74.

KERGA, E. et al. Teaching set-based concurrent engineering to practitioners through gaming. International Journal of Product Development, v. 19, n. 5/6, p. 348-365, 2014. http://dx.doi.org/10.1504/IJPD.2014.064884.

KESLACY, E. Fun and games: the suppression of architectural authoriality and the rise of the reader. Footprint, v. 17, p. 101-124, 2015.

KEYS, B.; WOLFE, J. The role of management games and simulations in education and research. Journal of Management, v. 16, n. 2, p. 307-336, 1990. http://dx.doi. org/10.1177/014920639001600205.

KIM, J.; CHUNG, K.; KANG, M. Continuous gesture recognition using HLAC and low-dimensional space. Wireless Personal Communications, v. 86, p. 255-270, 2015.

KNEZ, M.; CAMERER, C. Creating EXPECTATIONAL assets in the laboratory: coordination in 'weakest-link' games. Strategic Management Journal, v. 15, n. S1, p. 101-119, 1994. http://dx.doi.org/10.1002/smj.4250150908.

KNOTTS JUNIOR, U. S.; KEYS, J. B. Teaching strategic management with a business game. Simulation \& Gaming, v. 28, n. 4, p. 377-394, 1997. http://dx.doi. org/10.1177/1046878197284004.

KOSTOMAJ, M.; BOH, B. Design and evaluation of user's physical experience in an ambient interactive storybook and full body interaction games. Multimedia Tools and Applications, v. 54, n. 2, p. 499-525, 2010. http://dx.doi. org/10.1007/s11042-010-0549-4. 
KOTLER, P. Marketing para o século XXI: como criar, conquistar e dominar o mercado. São Paulo: Ediouro, 2009.

KUTBIDDINOVA, R.; EROMASOVA, A.; ROMANOVA, M. The use of interactive methods in the educational processo f higher education institution. International Journal of Environmental and Science Education, v. 11, n. 14, p. 6557-6572, 2016.

LAI, A. S. Y.; LEUNG, C. L. Ubiquitous bluetooth mobile based remote controller for home entertainment centre. In: PARK, D. S. et al. (Eds.). Advances in computer science and ubiquitous computing. Singapore: Springer, 2015. (Lecture Notes in Electrical Engineering, 373).

LAMB, R. Examination of the effects of dimensionality on cognitive processing in science: a computational modeling experiment comparing online laboratory simulations and serious educational games. Journal of Science Education and Technology, v. 25, n. 1, p. 1-15, 2016. http://dx.doi. org/10.1007/s10956-015-9587-z.

LAU, K. W. A study of student's learning experiences in creativity training in design education: an empirical research in virtual reality. Journal of Desert Research, v. 10, n. 3, p. 170-188, 2012.

LEE, C.-W. Influential factors of player's loyalty toward online games for achieving commercial success. Australasian Marketing Journal, v. 18, n. 2, p. 81-92, 2010. http:// dx.doi.org/10.1016/j.ausmj.2010.02.003.

LEOPOLDINO, K.; GONZÁLEZ, M.; MARQUES JUNIOR, J. Factors that contribute to collective creativity development in organizations. In: NORDDESIGN 2016: BIANNUAL CONFERENCE ON DESIGN AND DEVELOPMENT, 2016, Trondheim, Norway. Proceedings... Bristol: The Design Society, 2016. p. 237-247.

LOPES, P. C. Formação de administradores: uma abordagem estrutural e técnico-didática. 2001. 210 f. Tese (Doutorado)Universidade Federal de Santa Catarina, Florianópolis, 2001.

MARCO, J.; CEREZO, E.; BALDASSARRI, S. Lowering the threshold and raising the ceiling of tangible expressiveness in hybrid board-games. Multimedia Tools and Applications, v. 75, n. 1, p. 425-463, 2016. http://dx.doi.org/10.1007/ s11042-014-2298-2.

MARINHO, E. et al. Relationship between creativity and product innovation: a literature review. Product: Management \& Development, v. 14, n. 1, p. 32-37, 2016. http://dx.doi.org/10.4322/pmd.2016.007.

MARKIDES, C.; ANDERSON, J. Creativity is not enough: ICT-enabled strategic innovation. European Journal of Innovation Management, v. 9, n. 2, p. 129-148, 2006. http://dx.doi.org/10.1108/14601060610663532.
MCWILLIAM, E.; DAWSON, Z. S. Teaching for creativity: towards sustainable and replicable pedagogical practice. Higher Education, v. 56, n. 6, p. 633-643, 2008. http:// dx.doi.org/10.1007/s10734-008-9115-7.

MIHAI-YIANNAKI, S.; SAVVIDES, S. Creativity in business schools: post financial crisis implications. The International Journal of Organizational Analysis, v. 20, n. 2, p. 187 202, 2012. http://dx.doi.org/10.1108/19348831211227828.

MILLER, R.; OLLEROS, X.; MOLINIÉ, L. Innovation games: a new approach to the competitive challenge. Long Range Planning, v. 41, n. 4, p. 378-394, 2008. http://dx.doi. org/10.1016/j.lrp.2008.02.006.

MILLER, W. C. The creative edge: fostering innovation where you work. Reading: Addison-Wesley, 1987.

MILLER, W. C. Flash of brilliance: inspiring creativity where you work. Reading: Perseus, 1999.

MINGERS, J.; LEYDESDORFF, L. Identifying research fields within business and management: a journal cross-citation analysis. The Journal of the Operational Research Society, v. 66, n. 8, p. 1370-1384, 2015. http://dx.doi. org/10.1057/jors.2014.113.

MININA, V.; NIKITINA, I. Intellectual competition as technology for professional training of Managers. Journal of Management Development, v. 31, n. 3, p. 263-274, 2012. http://dx.doi.org/10.1108/02621711211208899.

NAKAMURA, J.; OHSAWA, Y.; NISHIO, H. An analogy game: toward cognitive upheaval through reflection-inaction. International Journal of Advanced Intelligence Paradigms, v. 2, n. 2, p. 1-12, 2010.

NISHINO, N. Co-creative value manufacturing: a methodology for treating interaction and value amongst artefacts and humans in society. Nanotechnology Perceptions, v. 9, n. 1, p. 6-15, 2013. http://dx.doi.org/10.4024/N19NI12A. ntp.09.01.

NONAKA, I. The knowledge-creating company. Harvard Business Review, v. 69, p. 96-104, 1991.

NONAKA, I.; TAKEUCHI, H. The knowledge-creating company: how japanese companies create the dynamics of innovation. Oxford: Oxford University Press, 1995.

OZKAN-CANBOLAT, E.; BERAHA, A. Evolutionary knowledge games in social networks. Journal of Business Research, v. 69, n. 5, p. 1807-1811, 2016. http://dx.doi. org/10.1016/j.jbusres.2015.10.060.

PAI, M. et al. Systematic reviews and meta-analyses: an illustrated step-by-step guide. The National Medical Journal of India, v. 17, n. 2, p. 86-95, 2004.

RIVERA, J.; DOMENICO, S.; SAUAIA, A. Influência da dissimilaridade de valores individuais no resultado de 
times de alta gerência: um estudo em laboratório de gestão. Revista Brasileira de Gestão de Negócios, v. 16, n. 50, p. 60-74, 2014. http://dx.doi.org/10.7819/rbgn.v16i50.1653.

ROBSON, K. et al. Is it all a game? Understanding the principles of gamification. Business Horizons, v. 58, n. 4, p. 411-420, 2015. http://dx.doi.org/10.1016/j.bushor.2015.03.006.

ROQUILLY, C. Control over virtual worlds by game companies: issues and recommendations. Management Information Systems Quarterly, v. 35, n. 3, p. 653-671, 2011. http://dx.doi.org/10.2307/23042802.

ROSA, M. et al. Business game and its relationship with creativity: a systematic literature review. In: INTERNATIONAL CONFERENCE ON ENGINEERING DESIGN (ICED 17), 21., 2017, Vancouver, Canada. Proceedings... Vancouver: ICED 17, 2017. p. 409-418. (Human Behaviour in Design, 8).

ROSSITER, M. State-based management. International Journal of Service Industry Management, v. 14, n. 4, p. 458470, 2003. http://dx.doi.org/10.1108/09564230310489277.

ROTHWELL, R. Successful Industrial Innovation: critical factors for the 1990s. R\&D Management, v. 22, n. 3, p. 221-240, 1992. http://dx.doi.org/10.1111/j.1467-9310.1992. tb00812.x.

ROWETON, W. Enhancing individual creativity in American business and education. The Journal of Creative Behavior, v. 23, n. 4, p. 248-257, 1989. http://dx.doi. org/10.1002/j.2162-6057.1989.tb00698.x.

SALDANA, J. et al. Online FPS games: effect of router buffer and multiplexing techniques on subjective quality estimators. Multimedia Tools and Applications, v. 71, n. 3, p. 1823-1856, 2014. http://dx.doi.org/10.1007/s11042012-1309-4.

SAVOLAINEN, T. Simulation games in CIM and the learning organization. Computers in Industry, v. 33, n. 2-3, p. 217-221, 1997. http://dx.doi.org/10.1016/S01663615(97)00027-4.

SCHÖN, D. A. The reflective practitioner: how professionals think in action. New York: Basic Books, 1983.

SCHUMPETER, J. A. New Translations from Theorie der wirtschaftlichen Entwicklung. American Journal of Economics and Sociology, v. 61, n. 2, p. 405-437, 2002. http://dx.doi.org/10.1111/1536-7150.00167.

SCHWARTZ, R.; TEACH, R. The CONGRUENCETM GAME: a team-building exercise for students of entrepreneurship. Simulation \& Gaming, v. 33, n. 1, p. 94-108, 2002. http:// dx.doi.org/10.1177/1046878102033001006.

SCHWEIGER, D. M.; ANDERSON, C. R.; LOCKE, E. A. Complex decision making: a longitudinal study of process and performance. Organizational Behavior and Human
Decision Processes, v. 36, n. 2, p. 245-272, 1985. http:// dx.doi.org/10.1016/0749-5978(85)90015-9.

SEIDEL, S.; MÜLLER-WIENBERGEN, F.; ROSEMANN, M. Pockets of creativity in business processes. Communications of the Association for Information Systems, v. 27, p. 415436, 2010. http://dx.doi.org/10.17705/1CAIS.02723.

SIGALA, M. The application and impact of gamification funware on trip planning and experiences: the chase of TripAdvisor's funware. Electronic Markets, v. 25, n. 3, p. 189-209, 2015. http://dx.doi.org/10.1007/s12525-0140179-1.

SISARICA, A. et al. Creativity support in a serious game for dementia care. In: ACM CONFERENCE ON CREATIVITY \& COGNITION, 9., 2013, Sydney, Australia. Proceedings... New York: ACM, 2013. p. 349-352. http:// dx.doi.org/10.1145/2466627.2466668.

SOEIRO, F.; SANTOS, M.; ALVES, J. Network-based innovation: the case for mobile gaming and digital music. European Business Review, v. 28, n. 2, p. 155-175, 2016. http://dx.doi.org/10.1108/EBR-07-2015-0072.

STORZ, C. Dynamics in innovation systems: evidence from Japan's game software industry. Research Policy, v. 37, n. 9, p. 1480-1491, 2008. http://dx.doi.org/10.1016/j. respol.2008.05.007.

SUSI, T.; JOHANNESSON, M.; BACKLUND, P. Serious games: an overview. Suécia: School of Humanities and Informatics, University of Skövde, 2007. Technical Report.

TANABE, M. Jogos de empresas. 1977. 117 f. Dissertação (Mestrado)-Faculdade de Economia, Administração e Contabilidade, Universidade de São Paulo, São Paulo, 1977.

VINICHENKO, M. et al. Modern views on the gamification of business. Journal of Internet Banking and Commerce, v. 21, n. 3, p. 1-13, 2016.

WALFISZ, M.; ZACKARIASSON, P.; WILSON, T. L. RealTime strategy: evolutionary game development. Business Horizons, v. 49, n. 6, p. 487-498, 2006. http://dx.doi. org/10.1016/j.bushor.2006.04.001.

WEBSTER, J.; WATSON, R. T. Analyzing the past to prepare for the future: writing a literature review. Management Information Systems Quarterly, v. 26, n. 2, p. 13-23, 2002.

WODEHOUSE, A.; BRADLEY, D. Gaming techniques and the product development process: commonalities \& crossapplications. Journal of Desert Research, v. 5, n. 2, p. 155-171, 2006.

WOLFE, J. The effects of game complexity on the acquisition of business policy knowledge. Decision Sciences, v. 9, n. 1, p. 143-155, 1978. http://dx.doi.org/10.1111/j.1540-5915.1978. tb01373.x. 
WRIGHT, A. It's all about games: enterprise and entrepreneurialism in digital games. New Technology, Work and Employment, v. 30, n. 1, p. 32-46, 2015. http:// dx.doi.org/10.1111/ntwe.12042.

ZACKARIASSON, P.; WÅHLIN, N.; WILSON, T. Virtual identities and market segmentation in Marketing in and through Massively Multiplayer Online Games (MMOGs). Services Marketing Quarterly, v. 31, n. 3, p. 275-295, 2010. http://dx.doi.org/10.1080/153 32969.2010 .486689 .
ZACKARIASSON, P.; WALFISZ, M.; WILSON, T. L. Management of creativity in video game development. Services Marketing Quarterly, v. 27, n. 4, p. 73-97, 2006. http://dx.doi.org/10.1300/J396v27n04_05.

ZACKARIASSON, P.; WILSON, T. Paradigm shifts in the video game industry. Competitiveness Review, v. 20, n. 2, p. 139151, 2010. http://dx.doi.org/10.1108/10595421011029857.

ZAVRŠNIK, J. et al. Sport education and society: bibliometric visualization of taxonomy. Journal of Physical Education and Sport, v. 16, n. 4, p. 1278-1286, 2016. 